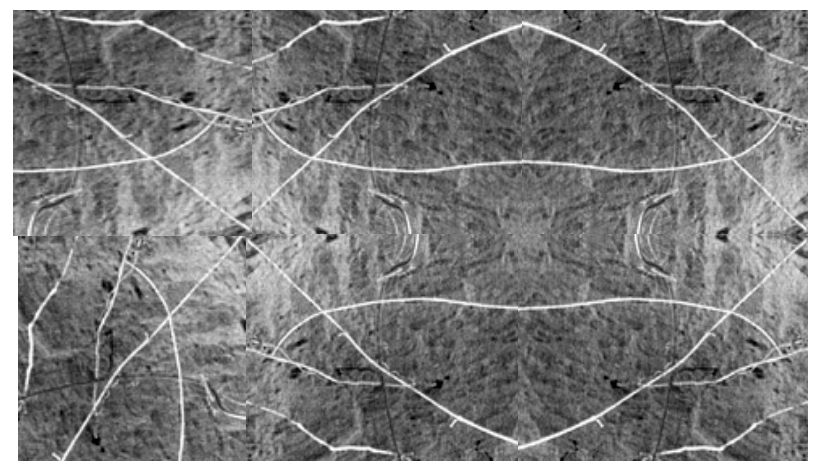

\title{
Saúde e envelhecimento: o autocuidado como questão
}

\section{Healthcare and aging: the issue of caring for one's self}

Neste estudo examinamos as relações entre autocuidado e envelhecimento, nas narrativas de idosos favelados da cidade de São Paulo. Partimos da premissa de que assistimos, nas sociedades ocidentais contemporâneas, a modos heterogêneos de conceber, de experimentar e de gerir o envelhecimento. Com base nesse pressuposto geral, procuramos revisitar os conceitos de velhice, cuidado, autocuidado $e$ promoção da saúde no envelhecimento.

A gestão da velhice, durante muito tempo considerada como própria da vida privada $e$ familiar, nos meados do século XX ganhou expressão e legitimidade no campo das preocupações sociais e transformou-se em uma questão da esfera pública. Porém, recentemente, o avanço das idades sofreu um processo de reprivatização, que recoloca o envelhecer e seus destinos sobre a responsabilidade individual, abrindo espaço, então, para que a velhice seja relativizada no leque das preocupações sociais do momento. No que se refere ao provimento de cuidados, esses processos tensionam o poder público, mas também a outras instituições $e$ organizações da sociedade civil, tais como as comunidades e as famílias.

Trata-se de estudo qualitativo no qual investigamos as formas de autocuidado adotadas pelos entrevistados, com ênfase na relação com os serviços de saúde.

Defendemos que o autocuidado não pode ser compreendido como simples adoção de saberes técnicos para a promoção da saúde, mas como uma atitude prática, relacionada à experiência de envelhecer, às condições de vida $e$ às interações familiar e comunitária. Propomos a necessidade de resistir à tendência de responsabilização individual do idoso pela sua saúde, freqüentemente associada às propostas de autocuidado.

\author{
Ângela Maria Machado de Lima \\ Tese de Doutorado, 2003 \\ Departamento de Medicina Preventiva, Faculdade \\ de Medicina, Universidade \\ de São Paulo, São Paulo \\ <sertao@usp.br>
}

PALAVRAS-CHAVE: Saúde; cuidado; promoção de saúde. KEY WORDS: Health; care; health promotion;

PALABRAS CLAVE: Salud; cuidado; promoción de la salud. 
TESES

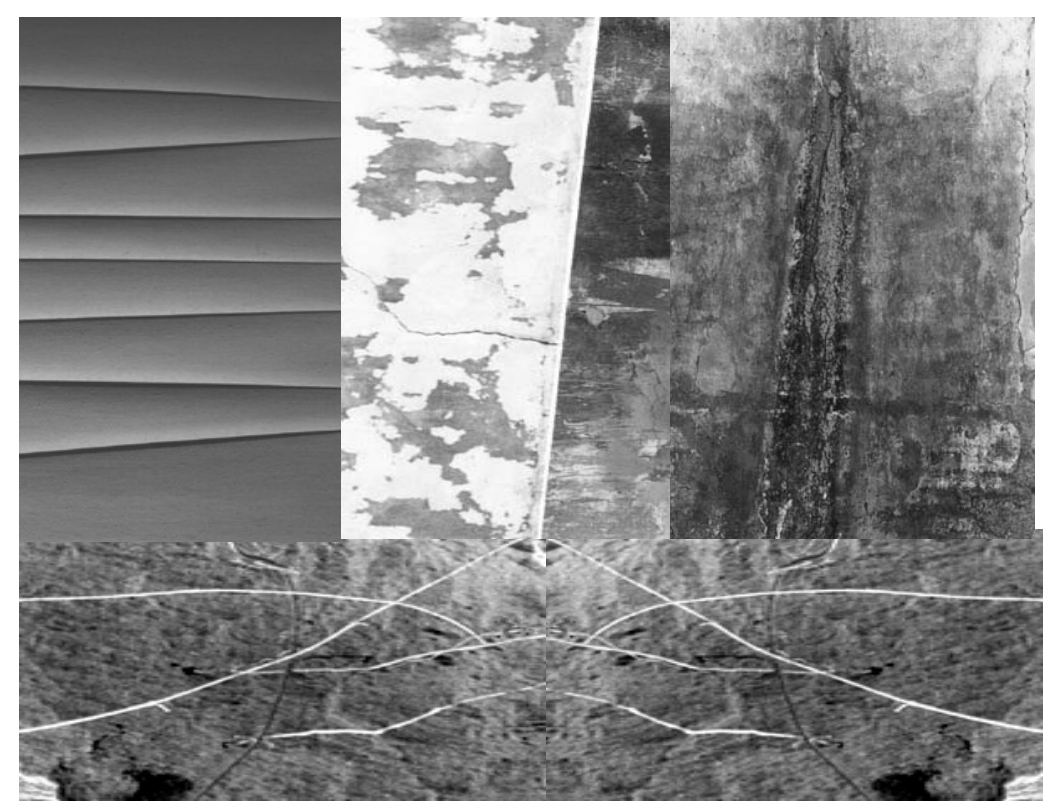

372 Interface - Comunic, Saúde, Educ, v8, n15, p.367-72, mar/ago 2004 